\title{
An Old Nubian Curse from the Faras Cathedral
}

\author{
VinCENT W.J. VAN GERVEN OEI
}

\begin{abstract}
The present paper analyses an Old Nubian inscription from the Faras Cathedral, containing a curse with a reference to Col 1:13. The publication gives a description of the inscription, a transcription with critical apparatus, and a grammatical and general commentary on the text.
\end{abstract}

Keywords: Christian Nubia, Faras, wall inscriptions, Old Nubian, curse, Biblical citations

Vincent W.J. van Gerven Oei, independent researcher, The Hague; vincent@vangervenoei.com; (D) 0000-0003-1637-4261

The following text from the Cathedral in Faras (field inv. no. B 34 a.3; National Museum in Warsaw inventory nos 234007 MN; DBMNT 2804) was first published by Stefan Jakobielski as Inscription 53. ${ }^{1}$ It was found on the first west pilaster in the North Aisle of the Cathedral, south face (Fig. 1). Only the end of the inscription, which Jakobielski correctly identified as Old Nubian, ${ }^{2}$ was preserved, but the ink drops splattered across the text from the first legible line downward suggest that the text extended an unknown number of lines upward. The inscription measures 34 x $46 \mathrm{~cm}$, with Nubian-type majuscules of an average height of $4.5 \mathrm{~cm}$ (Fig. 2). Based on the layer of plaster, Jakobielski dates the text between the beginning of the eleventh and the fifteenth century. The following transcription and translation are based on the photograph, transcription, and analysis provided by Jakobielski and autoptic examination by the author at the National Museum in Warsaw, where the inscription is on display.

1 Jakobielski 1974: 278, 308, Pl. 70.

2 Recently, three other Old Nubian inscriptions from the Faras Cathedral were published. See: Makowski, Van Gerven Oei 2016; Łajtar, Ochała 2017. 


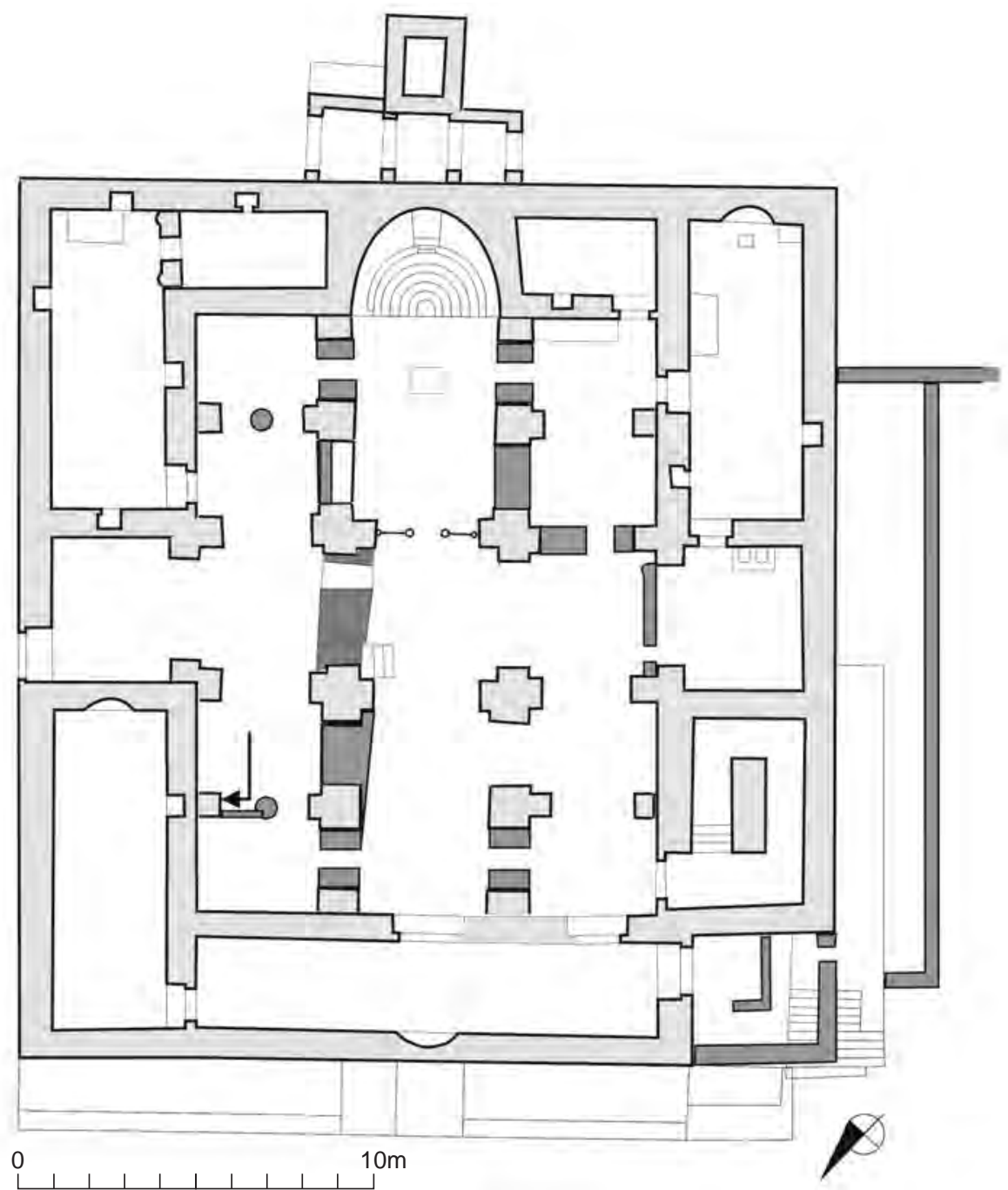

1. Plan of the Faras Cathedral with location of the inscription marked with an arrow; latter additions marked with darker shades (Digitising: D. Zielińska; based on: Godlewski 2006: Fig. 5).

[unknown number of lines missing]

1 [3-4] . apN $\lambda$

[3-4] eітіркаN

[No] $\overline{\mathrm{c} \kappa} \overline{\mathrm{T}} \mathrm{T} \bar{\lambda}$

4 TаK ав ПIMEN

àMH TaN LaN

ṕkaneda ōel s

بІPEK EגMEN

8 дмн: 
2. The inscription on display at the National Museum in Warsaw, inv. no. 234007 MN (Phot. V.W.J. van Gerven Oei).

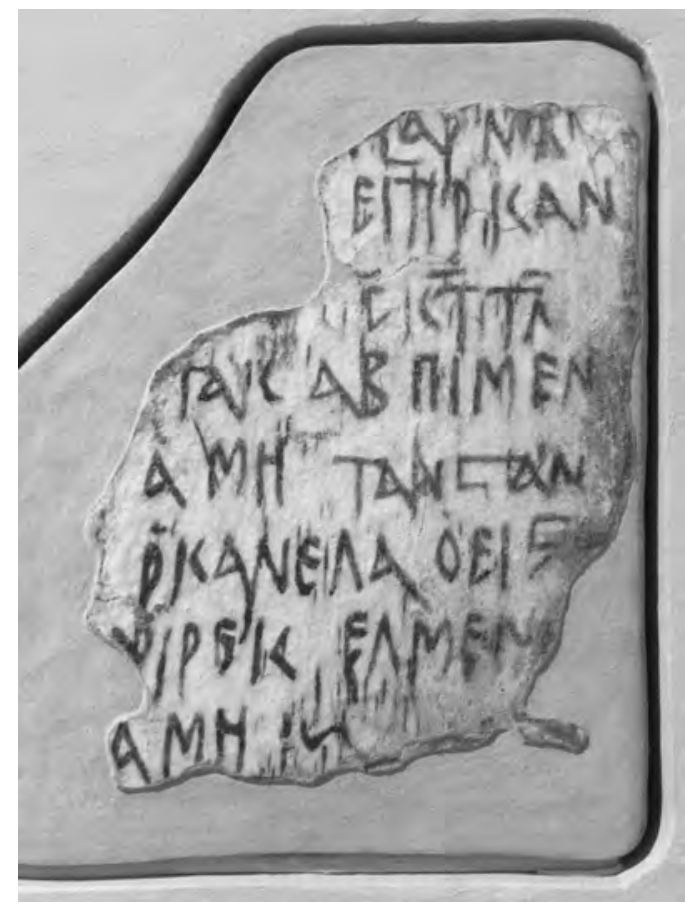

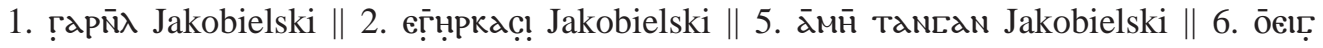
Jakobielski || 8. дмй Jakobielski

(...)

If he sends (...), may the earth not make and produce it, may he not find 6 foot to take in the kingdom of his son.

\section{GRAMMATICAL COMMENTARY}

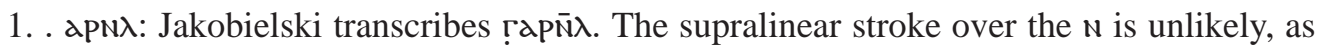
would be expected over the $\lambda$. A $\Gamma$ or perhaps even a $\mathrm{T}$ seems possible before the $\alpha$, with the latter giving us the pronomial form $\operatorname{Tap} N \bar{\lambda}$, which has been attested for example in P.QI II 13.i.4 Tap̄̄N $\bar{\lambda} .^{3}$

2. eiт̈ркам[no]: eiтp̄, 'to send'. ${ }^{4}$ The supralinear stroke over the $\mathrm{T}$ is unexpected and phonologically unnecessary (see the General Commentary). The ending - kan may be amended into the conditional ending $-\mathrm{KaN}_{\mathrm{N}}[\mathrm{No}]$ continuing on the next line, which has been

\footnotetext{
3 Browne 1989: 11.

${ }^{4}$ Browne 1996: 79.
} 


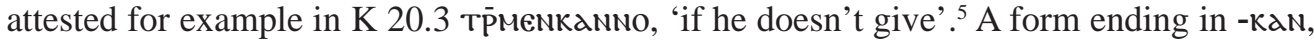
without the locative suffix but with the same meaning, is also possible, but this would leave an awkward gap at the beginning of line 3, where the subject $\bar{c} \kappa \bar{\top} \boldsymbol{T} \bar{\lambda}$ clearly marks the beginning of a new clause.

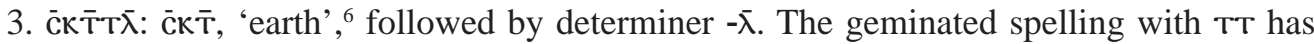
not been attested before. The two black traces before $\bar{c} \kappa \bar{\top} \tau \bar{\lambda}$ appear to be ink splatters, not

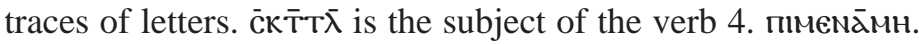

4. так: Accusative of the third person singular pronoun, object of 4. пाмєกа̄мн.

$\mathrm{a} \mathrm{B}$ : There is no attested Old Nubian word with this form, nor does it appear to follow Old Nubian phonological conventions. However, there is one other attested occurrence of the letter $\mathrm{B}$ being used to transcribe the semivowel /w/, namely in an unpublished bilingual Greek-Old Nubian version of Psalm 127 found in Old Dongola, where we find the variant

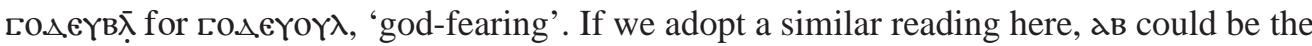
root a(Y)oү, 'to make', ${ }^{7}$ dependent on the verb 4. пाмєма̄mн.

пимєка̄мн: Jakobielski ${ }^{8}$ suggests a relation to the verb חı, 'to be, lie, remain', ${ }^{9}$ but since it is a transitive verb with an object, a relation to $\pi \epsilon \epsilon$, 'to grow, produce' or mi , 'to come out' $^{10}$ seems more likely. Such a meaning seems to be reinforced by the preceding verbal root $\mathbf{a}$. The verb itself has a negative suffix $-\mathbf{m} \in \mathbf{N}$, predicate marker $-\alpha$, and jussive $-\mathbf{m H}$.

5. Tan: Genitive of the third person singular pronoun.

[aN: Genitive of $\mathrm{Ld}(\lambda)$, 'son'.11

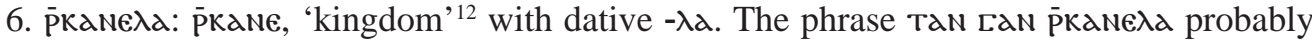

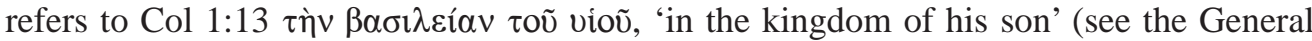
Commentary).

ōeı ؟: Possibly ōeı, 'foot', ${ }^{13}$ followed by a stigma, the Copto-Greek number $6, \varsigma$. It seems unlikely that the letter should be read as $\Sigma$, considering the fact that the scribe wrote this

\footnotetext{
5 Browne 1983: 11.

6 Browne 1996: 77.

7 Browne 1996: 13.

8 Jakobielski 1974: 308.

9 Browne 1996: 150.

10 Browne 1996: 148.

11 Browne 1996: 196.

12 Browne 1996: 140.

13 Browne 1996: 123.
} 
letter correctly on the previous line. Measurements in feet have been previously attested,

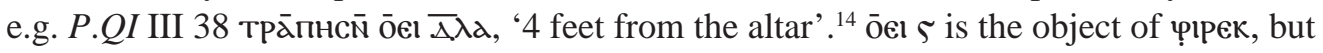

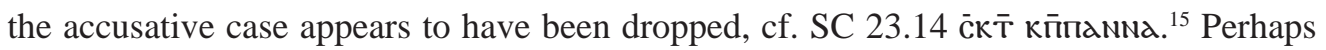
' 6 foot in the kingdom of his son' here refers metaphorically to the place of man in the Christian world.

7. ب̣ıєк: Unknown nominal form ending in accusative marker $-\kappa$, which marks the object of 7. елменамн, ōeı $\ulcorner$ чрірек. The final a is dropped, as usual, before the initial vowel of the subsequent word. As Old Nubian does not allow word-initial $\varphi$, perhaps we should assume a sublinear stroke that was either omitted or lost in the damage above the letter. In that we may be dealing with a verbal root $\bar{\varphi}$, followed by transitive marker -ip, and present tense $-\epsilon \lambda-\kappa>-\epsilon \kappa$, cf. P.QI I 4.i.26 סopeka. ${ }^{16}$ The verbal root $\bar{\varphi}$ may be related to $\bar{\varphi} \varphi$ 'to take, suffer' ${ }^{17}$ and Mattokki iny 'aufheben, fortnehmen, tragen, eine religiöse Pflicht erfüllen'. ${ }^{18}$

елменамн: Correctly identified by Jakobielski ${ }^{19}$ as a form of $e \lambda$, 'to find' ${ }^{20}$ The form is parallel to 4. пाмемд̄mн. A supralinear stroke over the a may have been lost and is no longer readable. A similar negative jussive is found in P.QI III $3034 \mathrm{e}^{\prime} \lambda^{\prime} \mathbf{M}^{\prime} \mathrm{M} \alpha \mathrm{MH}$ (see the General Commentary). ${ }^{21}$

\section{GENERAL COMMENTARY}

Although the ink splatters in line 1 suggest that the text extended upward for an unknown number of lines, the end of the text has been nearly fully preserved. It also appears that at least for the last 5 lines, both the left- and right-hand margins have been fully preserved. This state of preservation allows us to arrive at a partial translation.

The general meaning of the text hinges on the interpretation of the two main verbs, 4. пимема̄мн and 7. елмемамн. As both are formulated as negative jussives ('may not ...'), we concur with Jakobielski that it should not be identified as a prayer. However, the same forms also make it difficult to identify the text as an 'instruction' or 'canon', as Jakobielski suggests, which usually end in either an imperative or vetitive form ('do ...' or 'do not ...'). However, if our emendation and interpretation of 2. elт̄pкan[No] as a conditional is correct, we do find the syntactic structure 'if ..., may not ...'. This does not resemble so much of an instruction or rule, but rather the form of a curse.

\footnotetext{
14 Browne 1991: 16.

15 Browne 1984: 71.

16 Browne 1989: 19.

17 Browne 1996: 62.

18 von Massenbach 1933: 177.

19 Jakobielski 1974: 308.

20 Browne 1996: 56.

21 Browne 1991: 4.
} 
There is one other attested curse in Old Nubian, at the end of the royal proclamation $P . Q I$ III 30, ${ }^{22}$ which follows the same structure and indeed contains the same verbal form єлмєламн, 'may he not find'. ${ }^{23}$

\section{P.QI III 30 30-35}

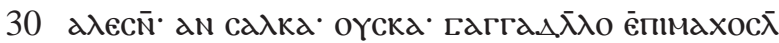

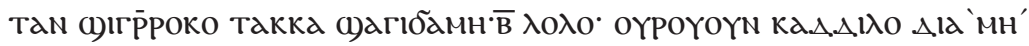

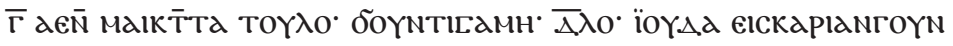

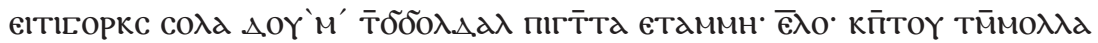

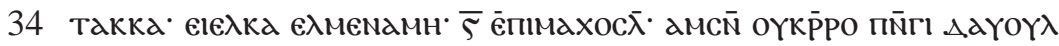

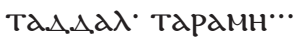

Whoever will speak against and deny my statement, let Epimachus stab him multiple times with his spear; 2. may he die from the king's curse; 3. may he begin to bear an affliction of the heart inside; 4. may he receive a share with Judas Iscariot, ${ }^{24}$ man-wounder and betrayer; 5. may he not find anyone who knows him among the assembled people; 6. may Epimachus on the Day of Judgment come (in) great battle against him.

The curse in P.QI III 30 follows the same construction as the one from the Faras Cathedral, starting with a conditional $a \lambda \epsilon \bar{\epsilon} \bar{N} \ldots$... гагга. $\lambda \bar{\lambda}$ o, followed by six jussive forms ending in - $\mathrm{\alpha MH}$.

Elsewhere in the Faras Cathedral, there is another bilingual Greek-Old Nubian inscription mentioning a curse, this time explicitly. ${ }^{25}$ I give here a transcription and translation of the Old Nubian part of the inscription that varies slightly from theirs:

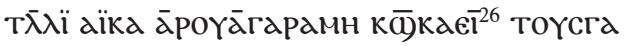

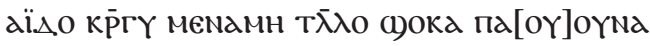

ceï̄єKa $\triangle € N A M H \bar{\alpha} M H N$

May God protect me. May the jealous ones not cause a curse to come up on me. May God give $m e^{27}$ the book of the inheritance of power. Amen.

22 Browne 1991: 4.

${ }^{23}$ A similar verbal form is found in another curse: P.QI III 41.18 мёкт̄тагдмн (Browne 1991: 22). See: Van Gerven Oei, Tsakos 2018 for discussion.

${ }^{24}$ Note that the Old Nubian form of Iscariot is eicкаріамгоүм, a genitive plural. This suggests that the Nubian scribe interpreted Iscariot in the tradition that etymologically derives it from the Latin sicarius, 'dagger man.'

25 Łajtar, Ochała 2017: 307-312, no. 2.

${ }^{26}$ Łajtar and Ochała suggest $\left.\kappa \bar{\alpha}\right)<\kappa \bar{\alpha}>\kappa a \in \overline{1}$. I do not think the reduplication needs to be introduced to render the same meaning.

${ }^{27}$ The benefactive verb $\Delta \mathrm{eN}$ implies a first person recipient. 
Interestingly, the prayer from the Faras Cathedral contains the word Toyc for 'curse', whereas P.QI III 30 has the word ka.A.A. The former is related to Andaandi tūs, 'curse' ${ }^{28}$ and Mattokki $t \bar{u} s$, 'fluchen, verwünschen, hassen', ${ }^{29}$ while the latter is related to Nobiin gar(i), 'schlecht, häßlich, böse, unglücklich', ${ }^{30}$ which has perhaps been loaned into Mattokki garri, 'schlecht, häßlich, Unglück bringend'. ${ }^{31}$ This distinction may represent a dialectal variation that has already been suggested by Adam Łajtar and Grzegorz Ochała. ${ }^{32}$

Our inscription also contains several interesting variants that may offer us a clue as to

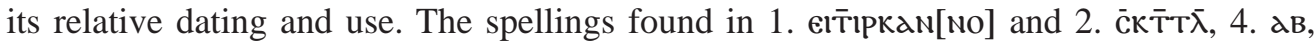
4. пімека̄мн, and 7. ب̣рєк have not been attested as such before. In general, the spelling is atypical and suggests that the scribe may not have been fully familiar with the literary language - because the text is of an unofficial nature, or is produced at a later stage of language development or during a period of decline in literacy. None of these explanations, which are moreover not mutually exclusive, can be preferred with any measure of certainty.

Thus, there seems to be a certain tension between the form and the content of this particular text. On the one hand, the execution in 'carefully written [...] large letters', which, as Jakobielski remarks, 'are well visible,' indeed suggests some type of officially sanctioned text, rather than a private prayer or visitor's graffito. This seems to be confirmed also by our analysis of the text, which identifies it as a curse. On the other hand, the multiple, previously unattested spelling variants suggest that the scribe was not educated in the tradition that has produced literary texts such as the pseudo-Nicene Canons. ${ }^{33}$ This would exclude a liturgical aim. Does this text therefore bear witness to a period in which the official use of Old Nubian was already in decline and the Cathedral in Faras past the heyday of the Makuritan state and church?

The curse appears to invoke both a worldly and a religious context. The first element of the curse, which threatens the reader an infertile $\bar{c} \kappa \bar{\top} \mathbf{T} \bar{\lambda}$, 'earth' that will no longer produce

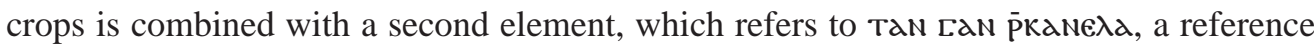

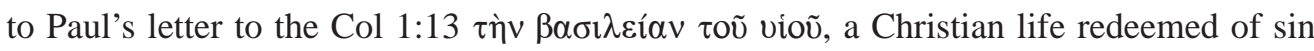
and death. The curse therefore appears to be addressed to a reader that is both Christian and familiar with the Scripture, but also part of an agrarian community. In other words, it does not seem to be directed to invading outsiders. This is also confirmed by the language in which the curse is written, Old Nubian. This does not only assume the Old Nubian literacy of the scribe, but also that those who were addressed by the curse were able to read it and understand its meaning.

\footnotetext{
${ }^{28}$ Armbruster 1965: 206.

29 von Massenbach 1933: 220.

30 Khalil 1996: 30.

31 von Massenbach 1933: 166.

32 Łajtar, Ochała 2017: 309.

33 Browne 1983.
} 
The fact that such a curse is written in large letters at a visible location in the church - otherwise a unique phenomenon in the context of Nubian church graffiti and dipinti - suggests that it may have been placed there after the regular use of the church had ceased. For such a curse would be unnecessary if at that point the church had still been in function, and vandalism or intruders not a reasonable threat. Perhaps the meaning of this inscription should be sought in this direction: a relic from a period, perhaps around the thirteenth century, in which Nubian-speaking Christians came under increased pressure from Muslim incursions from Egypt, and the Cathedral of Faras slowly vanished underneath the desert sand. ${ }^{34}$

\section{Acknowledgments}

The author would like to thank Adam Łajtar, Alexandros Tsakos, and two anonymous reviewers for their valuable comments on draft versions of this text, and Dobrochna Zielińska for preparing the plan.

\section{References}

Armbruster, C.H. 1965: Dongolese Nubian: A Lexicon, Cambridge

Browne, G.M. 1983: Griffith’s Nicene Canons, BASP 20/3-4, 97-112

Browne, G.M. 1984: Chrysostomus Nubianus: An Old Nubian Version of Ps. Chrysostom, In venerabilem crucem sermo, PapCastr 10, Rome

Browne, G.M. 1989: Old Nubian Texts from Qașr Ibrīm II, Texts from Excavations 10, London Browne, G.M. 1991: Old Nubian Texts from Qașr Ibrīm III, Texts from Excavations 12, London Browne, G.M. 1996: Old Nubian Dictionary, CSCO 556, Subsidia 90, Leuven

Gerven Oei, V. van, Tsakos, A. 2018: An Old Nubian Letter from the Daughter of an Eparch, Dotawo 5, 91-98

Godlewski, W. 2006: Pachoras: The Cathedrals of Aetios, Paulos and Petros. The Architecture, PAM Supplement Series 1, Warsaw

Jakobielski, S. 1972: A History of the Bishopric of Pachoras on the Basis of Coptic Inscriptions, Faras III, Warsaw

Jakobielski, S. 1974: Inscriptions, [in:] Michałowski, K., Jakobielski, S., Faras: Wall Paintings in the Collection of the National Museum in Warsaw, Warsaw, 277-309

Khalil, M.M. 1996: Wörterbuch der nubischen Sprache (Fadidja/Mahas-Dialekt), Nubica, Warsaw

Łajtar, A., Ochała, G. 2017: Two Private Prayers in Wall Inscriptions in the Faras Cathedral, EtudTrav XXX, 303-314

Makowski, P. with an appendix by Gerven Oei, V. van 2016: In Search of the Nubian Master-Builders: An Architectural Drawing from the Faras Cathedral, PAM XXV, 809-832

Massenbach, G. von 1933: Wörterbuch des nubischen Kunûzi-Dialektes mit einer grammatischen Einleitung, MSOSAfr XXXVI, 99-227

\footnotetext{
34 Jakobielski 1972: 167.
} 


\section{ÉTUDES et TRAVAUX XXXII / 2019}

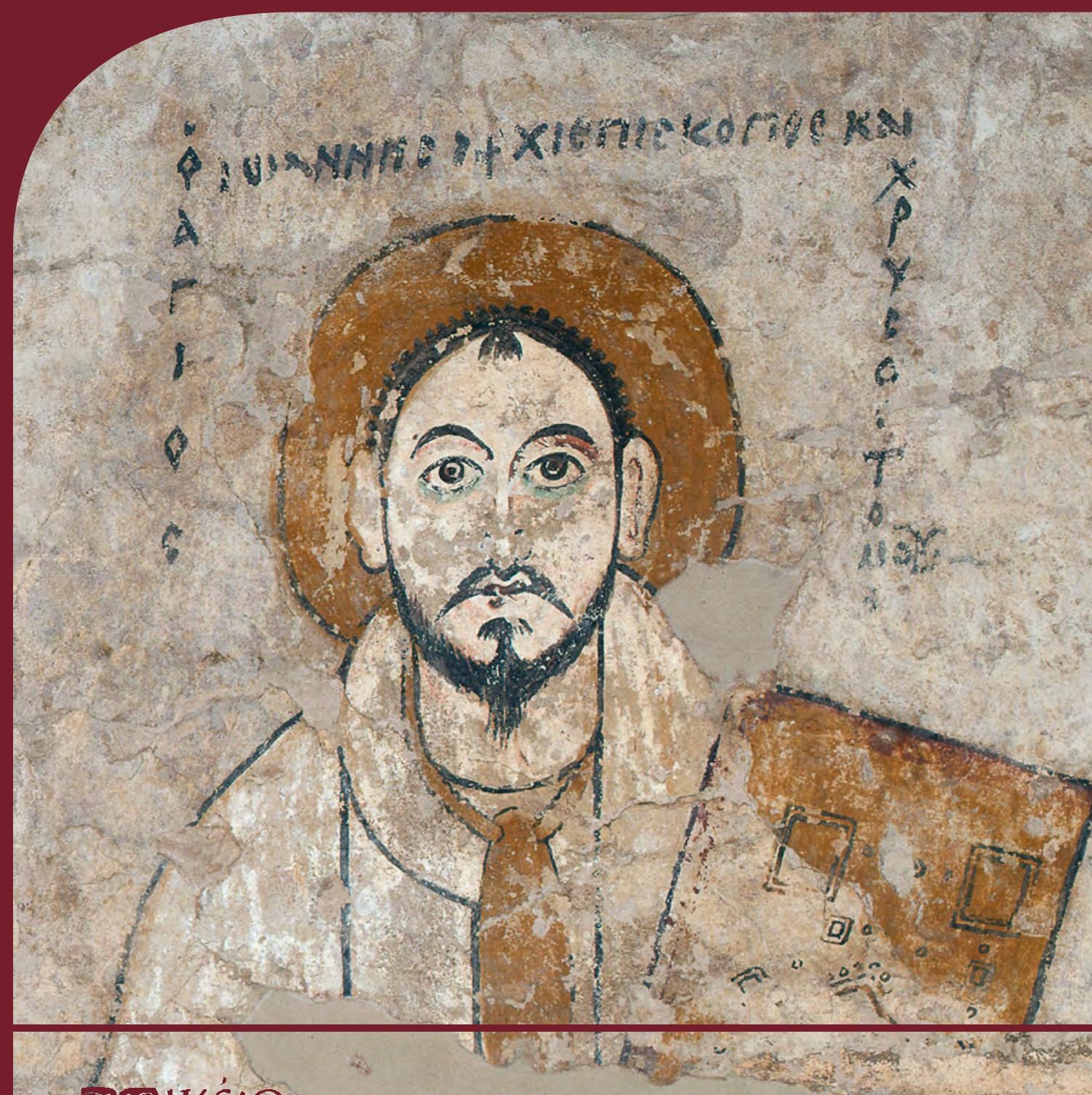

BOMIKSiO Institut des Cultures Méditerranéennes et Orientales ED2A PAN de l'Acácémie Polonaise des Sciences 


\title{
COMITÉ DE RÉDACTION SCIENTIFIQUE
}

Maciej Makowski - rédacteur en chef Jadwiga Iwaszczuk - rédacteur

Maciej G. Witkowski - rédacteur

Agnieszka Ryś - sécretaire de la rédaction

Bogdan Żurawski - rédacteur thématique du volume

CONSEIL SCIENTIFIQUE DU JOURNAL

M. Kobusiewicz (IAE PAN, Warszawa), E. Laskowska-Kusztal (IMOC PAS, Warszawa),

D. Michaelides (University of Cyprus, Nicosia),

J.Ch. Moretti (IRAA-MOM, Université de Lyon 2/CNRS),

D. Raue (Ägyptisches Museum der Universität Leipzig), P. Reynolds (ICREA, España),

D. Welsby (British Museum, London)

\section{COMITÉ SCIENTIFIQUE DE LECTURE}

D.E. Arnold (Wheaton College/The Field Museum, Chicago), H.D. Baker (University of Toronto),

P. Ballet (ArScAn-ESPRI, Université Paris Nanterre), Ch. Barber (Princeton University),

N. Beaux-Grimal (IFAO, Caire/Collège de France, Paris), A. Boud'hors (CNRS, IRHT, Paris),

J. Budka (Ludwig-Maximilians-Universität München), R. David (SFDAS),

A. Delattre (CPEG, Bruxelles), A. Dodson (University of Bristol),

E. Fogliadini (Facoltà Teologica dell'Italia Settentrionale, Milan),

V. Francigny (CNRS/CRES, Paris), L. Gabolde (CNRS), C. Gobeil (Egypt Exploration Society, London),

N. Hamdi (UCL, Louvain), J. den Heijer (CIOL/INCAL, Louvain-la-Neuve),

S. Ikram (American University in Cairo), Ch. Leitz (Universität Tübingen), S. Ortisi (Universität München),

E. Rova (Università Ca' Foscari Venezia), G. Ruffini (Fairfield University),

A. Sasson (San Diego Natural History Museum), H. Satzinger (Universität Wien),

S.M. Schellinger (The Ohio State University, Columbus), G. Schreiber (Eötvös Loránd University, Budapest),

E. Teeter (University of Chicago), S. Torallas-Tovar (University of Chicago),

Y. Tristant (Macquarie University, Sydney), V. Vaelske (independent researcher),

H. Vymazalová (Charles University, Prague), P. Weschenfelder (Universität Wien),

B. Williams (University of Chicago/PCMA UW, Warszawa),

K. Winther-Jacobsen (The Danish Institute at Athens), E. Zacharopoulou (University of Johannesburg),

P. Grotowski (UPJPII, Kraków), E. Papuci-Władyka, J. Śliwa (IA JU, Kraków), A. Ćwiek (IA AMU, Poznań),

K.O. Kuraszkiewicz, M. Pinker (FOS UW, Warszawa), Ł. Niesiołowski-Spanò (IH UW, Warszawa),

M. Gawlikowski, Mahmoud El-Tayeb (PCMA UW, Warszawa), S. Rzepka (IA UW, Warszawa)

\author{
RÉDACTION TECHNIQUE \\ Monika Wesołowska
}

REVUE DES TEXTES ANGLAIS

Jo Harper 
ÉTUDES et TRAVAUX

XXXII 
INSTYTUT KULTUR ŚRÓDZIEMNOMORSKICH I ORIENTALNYCH POLSKIEJ AKADEMII NAUK

\title{
STUDIA i PRACE
}

\author{
XXXII
}

gू IKŚiO

ESAN

WARSZAWA

2019 
INSTITUT DES CULTURES MÉDITERRANÉENNES ET ORIENTALES DE L’ACADÉMIE POLONAISE DES SCIENCES

\section{ÉTUDES et TRAVAUX}

XXXII

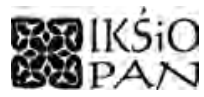

VARSOVIE

2019 
Publication scientifique financée dans le cadre du programme du Ministre de la Science et de l’Éducation Supérieure

« Programme National de Développement de l’Humanistique » pour les années 2016-2021 (projet no $3 b H 150099$ 83)

\title{
TI NARODOWY PROGRAM ROZWOJU HUMANISTYKI
}

\author{
Copyright $(\mathbb{C}$ \\ Instytut Kultur Śródziemnomorskich i Orientalnych PAN \\ et les Auteurs \\ Warszawa 2019
}

\begin{abstract}
ISSN 2084-6762
(avant 2011 : 0079-3566)

e-ISSN 2449-9579

Version première en papier, imprimée en Pologne - 150 copies

Version électronique accessible sur

http://www.etudesettravaux.iksiopan.pl
\end{abstract}

Édition: Polskie Towarzystwo Historyczne et Wydawnictwo Neriton, Warszawa

Conception générale de couverture : J. Iwaszczuk

Photo de couverture : P. Ligier ; courtoisie du Musée National de Varsovie

(Saint Jean Chrysostome, peinture, cathédrale de Faras). 


\section{Table des matières}

Editorial: Quid novi ex Nubia (par Bogdan Żurawski) ............................................... 7

Bibliography of Professor Stefan Jakobielski ................................................................ 13

Aneta Cedro, Bogdan Żurawski

Living with the Past in Modern Sudanese Village. Traditional Pottery Production

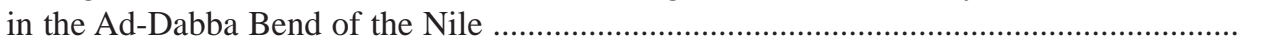

DAVID N. EDWARDS

A Possible Monastery and the 'Upper Maqs’ at Ukma-Akasha West? ............................ 53

Vincent W.J. van GeRven OeI

An Old Nubian Curse from the Faras Cathedral ........................................................ 81

Vincent W.J. van Gerven Oei, Adam Łajtar

Two Old Nubian Inscriptions from Akasha West ........................................................ 89

Vincent W.J. van Gerven Oei, Alexandros Tsakos

Rubrication Patterns in Two Old Nubian Manuscripts from Serra East .......................... 99

KAREL C. INNEMÉE

A Man in a Vessel, Once More .................................................................................. 111

KAREL C. INNEMÉE, Dobrochna ZielińSKA

Faces of Evil in Nubian Wall-Painting - An Overview ................................................ 121

ADAM ŁAJTAR

Epitaph of Merki Found in Hambukol ....................................................................... 145

MAGDALENA ŁAPTAŚ

Attributes, Vestments, Context and Inscription in the Identification of Nubian

Paintings: Proposing the 'Multi-Layer' Image Recognition Method ............................... 161

Grzegorz Ochala

Nubica Onomastica Miscellanea I: Notes on and Corrections to Personal Names

Found in Inscriptions from Faras 


\section{Robin SEIGNOBOS}

L'influence du Kitāb ahbār al-Nūba d'Ibn Sulaym al-Uswānī sur l'Histoire des églises et monastères d'Égypte d'Abū al-Makārim

JACQUES VAN DER VLIET

Exit Bishop Tamer - the Sequel. A New Edition of the Epitaph of Papsine alias Doulista (DBMNT 78) 